\title{
Measures of health-related quality of life in diabetes-related foot disease: a systematic review
}

\author{
F. R. A. Hogg • G. Peach • P. Price • M. M. Thompson • \\ R. J. Hinchliffe
}

Received: 8 July 2011 /Accepted: 20 September 2011 / Published online: 14 January 2012

(C) Springer-Verlag 2012

\begin{abstract}
Aims/hypothesis Patient-reported outcome measures (PROMs) are increasingly used as key performance indicators in chronic illness. We sought to review the value of these tools in assessing health-related quality of life (HRQOL) in patients with diabetes-related foot disease and identify the impact of each foot problem on life quality.

Methods A systematic review of literature on HRQOL PROMs in diabetes-related foot disease was performed according to Preferred Reporting Items for Systematic Reviews and Meta-analyses (PRISMA) guidelines. The quality of eligible studies was evaluated within pre-existing criteria.

Results 53 studies written between 1995 and 2010 met the inclusion criteria. A variety of HRQOL PROMs were used. Disease-specific tools were better than generic at quantifying temporal changes in life quality and showed greater sensitivity to ulcer/neuropathic severity. No studies have simultaneously evaluated disease-specific tools. Generic and utility HRQOL PROMs are frequently used as secondary outcome measures in randomised trials and cost-utility analysis.

HRQOL is depressed in diabetes, further impaired by the presence of foot disease. Ulcer healing is associated with improvements in HRQOL. Patients with active ulceration report poorer HRQOL than those whom have undergone
\end{abstract}

F. R. A. Hogg • G. Peach • M. M. Thompson •

R. J. Hinchliffe $(\bowtie)$

St George's Vascular Institute,

St James Wing, St George's Healthcare NHS Trust,

4th Floor, Blackshaw Road,

London SW17 0QT, UK

e-mail: rhinchli@sgul.ac.uk

P. Price

School of Healthcare Studies, Cardiff University,

Cardiff, UK successful minor lower extremity amputation (LEA) but there is a paucity of quality data on HRQOL outcomes for diabetes-related LEA.

Conclusions/interpretation No one PROM was identified as a 'gold standard' for assessing HRQOL in diabetes-related foot disease. Specific areas for further development include the most valid HRQOL PROM with disease-specific content; HRQOL outcomes in minor and major amputations and the role of HRQOL tools in routine clinical care.

Keywords Amputation - Diabetic foot disease - Healthrelated quality of life - Patient-reported outcome measures . Peripheral neuropathy $\cdot$ Ulcer
Abbreviations
CWIS
DFS
DFS-SF
DFU
DPN
EQ-5D
HRQOL
LEA
NICE
Cardiff Wound Index Scale
Diabetic Foot Ulcer Scale
Diabetic Foot Ulcer Scale Short
Form
Diabetic foot ulcer
Diabetes-related peripheral neuropathy
EuroQOL 5D Health Utility Index
Health-related quality of life
Lower extremity amputation
National Institute for Health and
Clinical Excellence
Norfolk QoL-DN
Norfolk Quality of Life in Diabetic
PROM
RAND-36
Neuropathy Questionnaire
Patient-recorded outcome measure
SF-12
Research and Development 36-item
Form
Medical Outcomes Study 12-item
Short-Form Health Survey
SF-36
Medical Outcomes Study 36-item
Short-Form Health Survey 


\section{Introduction}

Management of diabetes-related foot disease demands a multidisciplinary approach with treatments that are often intensive and prolonged. As a result, hospitalisations are frequent and costs are high. Evidence to support any one approach over another, in terms of conventional endpoints such as wound healing or major amputation, is thin [1]. Given the lack of clear benefit in terms of conventional outcome measures, the use of other markers of treatment success may be more appropriate.

One such marker is health-related quality of life (HRQOL). HRQOL is a subjective measure of a person's physical and psychological well-being and represents a patient's assessment of how a particular disease or intervention has affected their life. Information about a patient's HRQOL is commonly gathered using 'PatientReported Outcome Measures' (PROMs). These involve the patient responding to a number of questions on themes such as physical functioning, social functioning and mental wellbeing, and may include both generic and disease-specific questions. Responses are analysed to produce a multidimensional quality of life 'score' that can be measured repeatedly to help clinicians identify an improvement or deterioration in a patient's health status. The use of PROMs has been recommended in the evaluation of healthcare technologies/services and in regulatory decision-making in the UK National Health Service (NHS) [2].

The purpose of this review is to summarise and analyse the literature pertaining to HRQOL PROMs used in the spectrum of diabetes-related foot disease. Specifically, we aim to assess the validity of HRQOL PROMs and examine specific factors affecting HRQOL in patients with diabetes and foot disease.

\section{Methods}

Systematic searches using the keywords 'diabetes mellitus and foot' OR 'diabetic foot' AND 'neuropathy/ulcer/ Charcot arthropathy/amputation/lower extremity amputation' AND 'health related quality of life/quality of life/ QALY/patient reported outcome measure' were performed using the 'explosion technique' where possible in Medline, PubMed, EMBASE and the Cochrane Library. Articles were limited to English language, human studies and peer review publications, and included all papers identified from 1966 to 7 February 2011. Bibliographies of relevant citations were screened for further articles of relevance.

Inclusion criteria specified that studies had to assess HRQOL specifically pertaining to foot health in patients with diabetes using structured PROMs. Studies using PROMs to look at general aspects of HRQOL in diabetes were excluded, as were studies that used 'self-evaluation' (i.e. free texting/interviews without formulaic format) as a means of recording HRQOL.

HRQOL PROMs were rated according to pre-defined criteria (assessing study quality, quality of tool employed and the generalisability of outcomes) [3]. The score was adapted to ensure its relevance to diabetes-related foot disease [4] and an overall quality 'score' (range, 0-15) was assigned as a gross marker of fulfilment of the criteriawhere 0 represented poorest quality and 15 best quality.

The literature review conformed to Preferred Reporting Items for Systematic Reviews and Meta-analyses (PRISMA) statement standards $[5,6]$. Owing to heterogeneity of study design, varying methodology and PROMs used, a quantitative pooled meta-analysis was not performed.

\section{Results}

Initial search strategies revealed 203 papers. When abstracts and reference lists were scrutinised and exclusion/inclusion criteria applied, 53 studies were eligible and included (Fig. 1). The median quality 'score' [3] of the 53 included studies assessed was 10 (range 4-15) (Table 1).

PROMs used to assess HRQOL in diabetes-related foot disease

A variety of generic, summary, utility, dimension specific, disease-specific and site-specific PROMs were used to assess HRQOL in diabetes-related foot disease (Tables 1 and 2).

Generic PROMs The most frequently encountered tool, used in 27 studies, was the generic HRQOL tool: the Medical Outcomes Study 36-item Short-Form Health Survey (SF-36) (http://www.qualitymetric.com). The SF36 is commonly used as a 'gold standard' PROM to verify construct validity when developing disease-/site-/dimension-specific PROMs. It has shown efficacy in assessing HRQOL in diabetes-related foot disease [7-18] (Fig. 2). When evaluated alongside site-/disease-specific PROMs, the Diabetic Foot Ulcer Scale (DFS) [10-12] and the Cardiff Wound Index Scale (CWIS) [8, 19], statistically significant correlations between the assessed 'life domains' (e.g. locomotor abilities, mental wellness, personal care) make it an appropriate measure (Fig. 3).

The SF-36 has shown sensitivity when correlating HRQOL scores with diabetic foot ulcers (DFUs) [13] and neuropathy severity [20]. Furthermore it can show temporal changes in HRQOL [21] and has been used in a number of randomised controlled trials assessing the treatment of diabetes-related foot disease $[9,12,22-26]$ in which improvements in primary outcomes (i.e. ulcer healing and 
Fig. 1 Preferred Reporting Items for Systematic Reviews and Meta-Analyses (PRISMA) 2009 flow diagram

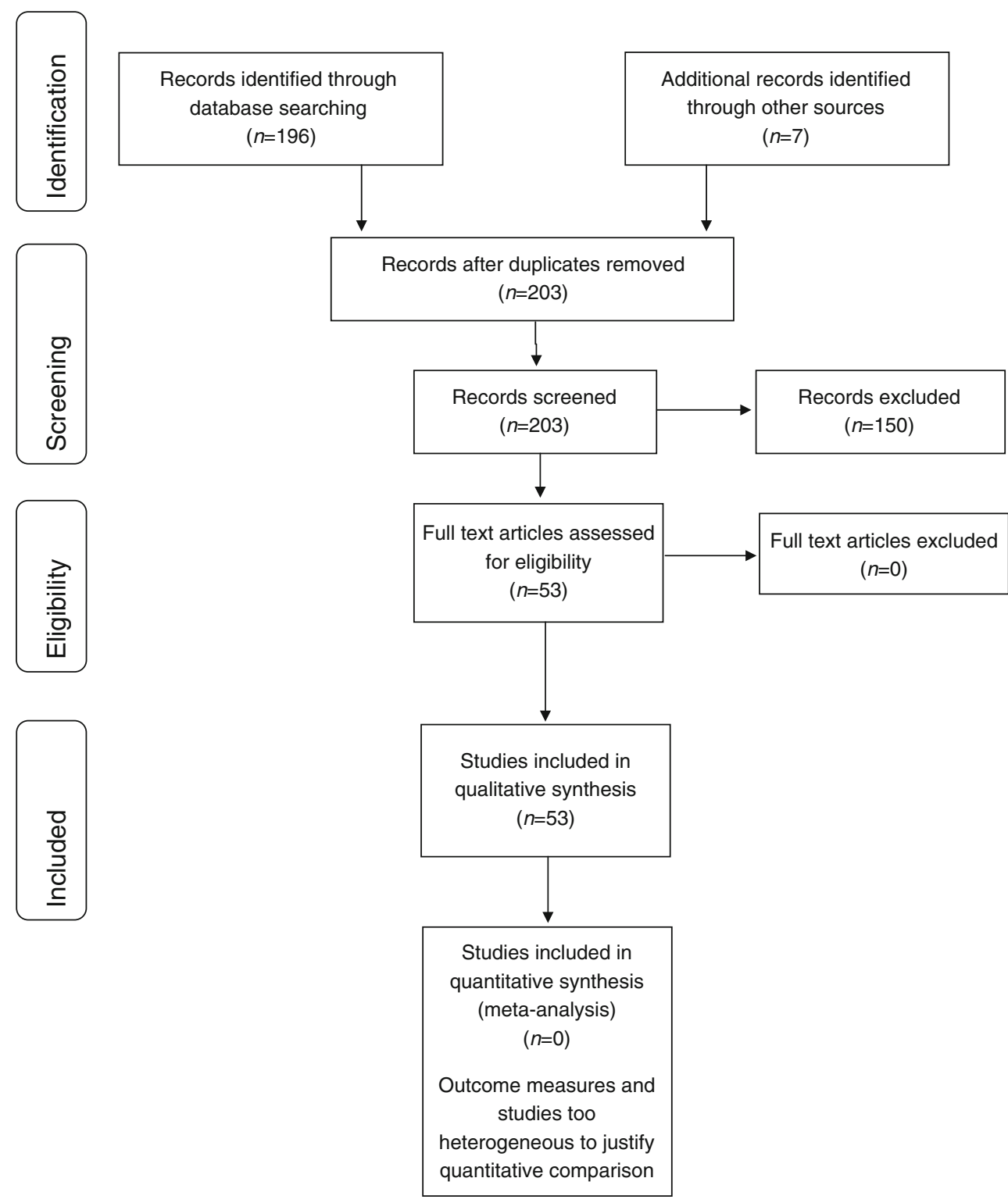

improved pain scores) were associated with appropriate changes in HRQOL scores.

In contrast, a Nottingham-based randomised controlled trial assessing the use of different dressing types in the treatment of DFUs used the SF-36 alongside the CWIS to document HRQOL as a secondary outcome measure. Whereas the CWIS showed statistically significant improvements in HRQOL between healed and non-healed ulcers, the SF-36 failed to show any difference [27]. This poor sensitivity to ulcer healing was presumed by the study group to relate to the large volume of incomplete SF-36 questionnaires at follow-up, suggesting that it is a poorly accepted tool. Most observational studies assessed by this review have, however, reported good response rates of $>70 \%$ when using the SF- 36 .

The SF-36 is well equipped to generate a generic measure of HRQOL and can be truncated into the Medical Outcomes Study 6D Short-Form Health Utility Index (SF-
6D) for health utility analysis. However, the SF-36 lacks specificity and may be confounded by other (non-foot) complications of diabetes [13, 14].

Other generic measures of HRQOL (the Medical Outcomes Study 12-item Short-Form Health Survey [SF-12], the Research and Development 36-item Form [RAND-36], the Nottingham Health Profile, the Sickness Index Profile) show appropriate changes in HRQOL according to severity of foot disease [28-31] but remain subject to confounding factors as a result of poor specificity.

Health utility PROMs Health utility PROMS have been used for the economic evaluation of foot care/treatment in diabetes with variable outcomes in terms of calculated health states (Table 2). To ensure comparability between cost-utility analyses and to guide healthcare resource allocation, the National Institute for Health and Clinical 
Table 1 Eligible studies assessing HRQOL in diabetic foot disease

\begin{tabular}{|c|c|c|c|c|}
\hline Reference & Study design & Study aims & PROM used & $\begin{array}{l}\text { Quality } \\
\text { score }\end{array}$ \\
\hline $\begin{array}{l}\text { Eckman et al, } \\
\text { USA, } 1995 \text { [41] }\end{array}$ & Cost-utility & $\begin{array}{l}\text { To determine outcomes in } \\
\text { management of foot infection/ } \\
\text { osteomyelitis in T2DM }\end{array}$ & SF-36 & 6 \\
\hline $\begin{array}{l}\text { Carrington et al, } \\
\text { UK, } 1996[33]\end{array}$ & Cross-sectional & $\begin{array}{l}\text { To compare the HRQOL of diabetic } \\
\text { patients with chronic DFU, LEA } \\
\text { and controls without foot disease }\end{array}$ & $\begin{array}{l}\text { Quality of Life Ladder } \\
\text { Foot questionnaire }\end{array}$ & 7 \\
\hline $\begin{array}{l}\text { Armstrong et al, } \\
\text { USA, } 1997 \text { [51] }\end{array}$ & Longitudinal & $\begin{array}{l}\text { To evaluate pulsed-dose electrical } \\
\text { stimulation as an analgesic modality } \\
\text { in patients with painful DPN (HRQOL } \\
\text { as a secondary outcome) }\end{array}$ & $10 \mathrm{~cm}$ VAS & 7 \\
\hline $\begin{array}{l}\text { Backonja et al, } \\
\text { USA, } 1998 \text { [52] }\end{array}$ & Randomised controlled trial & $\begin{array}{l}\text { To evaluate the use of gabapentin } \\
\text { monotherapy in painful DPN } \\
\text { (HRQOL as a secondary outcome) }\end{array}$ & SF-36 & 13 \\
\hline $\begin{array}{l}\text { Benbow et al, } \\
\text { UK, } 1998[28]\end{array}$ & Cross-sectional & $\begin{array}{l}\text { To assess HRQOL and pain scores } \\
\text { in patients with DPN }\end{array}$ & $\begin{array}{l}\text { Nottingham Health Profile } \\
10 \mathrm{~cm} \text { VAS }\end{array}$ & 11 \\
\hline $\begin{array}{l}\text { Piaggesi et al, } \\
\text { Italy, } 1998 \text { [53] }\end{array}$ & Randomised controlled trial & $\begin{array}{l}\text { To assess the surgical vs non-surgical } \\
\text { management of DFU }\end{array}$ & $10 \mathrm{~cm}$ VAS & 5 \\
\hline $\begin{array}{l}\text { Davies et al, } \\
\text { UK, } 2000 \text { [48] }\end{array}$ & Longitudinal & $\begin{array}{l}\text { To assess the impact of orthotic } \\
\text { treatment on HRQOL in diabetes- } \\
\text { related foot disease }\end{array}$ & SF-36 & 10 \\
\hline $\begin{array}{l}\text { Tennvall and Apelqvist, } \\
\text { Sweden, } 2000[43,44]\end{array}$ & Cross-sectional & $\begin{array}{l}\text { To assess HRQOL in patients with } \\
\text { diabetes: with current DFU, primary } \\
\text { healed DFU, a history of minor LEA } \\
\text { and a history of major LEA }\end{array}$ & EQ-5D with $10 \mathrm{~cm}$ VAS & 13 \\
\hline $\begin{array}{l}\text { Meijer et al, } \\
\text { Holland, 2001 [29] }\end{array}$ & Cross-sectional & $\begin{array}{l}\text { To compare the HRQOL of patients } \\
\text { with and without DFU }\end{array}$ & $\begin{array}{l}\text { RAND-36 } \\
\text { Barthel Score } \\
\text { WSQ }\end{array}$ & 12 \\
\hline $\begin{array}{l}\text { Peters et al, } \\
\text { USA, } 2001[30]\end{array}$ & Cross-sectional & $\begin{array}{l}\text { To assess functional levels in patients } \\
\text { with diabetes post LEA }\end{array}$ & SIP & 11 \\
\hline $\begin{array}{l}\text { Abetz et al, } \\
\text { UK, } 2002[12]\end{array}$ & Longitudinal & $\begin{array}{l}\text { To assess validity/reliability } \\
\text { of the DFS tool }\end{array}$ & $\begin{array}{l}\text { DFS } \\
\text { SF-36 }\end{array}$ & 15 \\
\hline $\begin{array}{l}\text { Coffey et al, } \\
\text { USA, } 2002 \text { [54] }\end{array}$ & Cross-sectional/Cost-utility & $\begin{array}{l}\text { To describe the health utilities associated } \\
\text { with diabetes and its treatments, } \\
\text { complications and co-morbidities }\end{array}$ & QWB-SA & 10 \\
\hline $\begin{array}{l}\text { Pinzur, et al, } \\
\text { USA, } 2003 \text { [40] }\end{array}$ & Cross-sectional & $\begin{array}{l}\text { To evaluate the HRQOL of patients } \\
\text { with Charcot arthropathy }\end{array}$ & $\begin{array}{l}\text { SF-36 } \\
\text { AAOS }\end{array}$ & 8 \\
\hline $\begin{array}{l}\text { Vileikyte et al, } \\
\text { USA + UK, } 2003 \text { [31] }\end{array}$ & Cross-sectional & To develop and validate NeuroQoL & $\begin{array}{l}\text { NeuroQoL } \\
\text { SF-12 }\end{array}$ & 13 \\
\hline $\begin{array}{l}\text { Price and Harding, } \\
\text { UK, 2004, [8] }\end{array}$ & $\begin{array}{l}\text { Focus groups, pilot study, } \\
\text { cross-sectional }\end{array}$ & $\begin{array}{l}\text { To document the development of } \\
\text { the CWIS and to validate it }\end{array}$ & $\begin{array}{l}\text { CWIS } \\
\text { SF-36 }\end{array}$ & 11 \\
\hline $\begin{array}{l}\text { Rosenstock et al, } \\
\text { USA, } 2004 \text { [26] }\end{array}$ & Randomised controlled trial & $\begin{array}{l}\text { To evaluate pregabalin in painful DPN } \\
\text { (HRQOL as a secondary outcome) }\end{array}$ & SF-36 & 9 \\
\hline $\begin{array}{l}\text { Dhahwan et al, } \\
\text { USA, } 2005 \text { [55] }\end{array}$ & Cross-sectional multicentre & $\begin{array}{l}\text { To document the development of and } \\
\text { evaluate a Charcot arthropathy-specific } \\
\text { HRQOL tool }\end{array}$ & AOFAS-DFQ & 7 \\
\hline $\begin{array}{l}\text { Evans and Pinzur, } \\
\text { USA, } 2005 \text { [56] }\end{array}$ & Cross-sectional & $\begin{array}{l}\text { To perform a feasibility trial using AAOS } \\
\text { to assess HRQOL in DFU }\end{array}$ & AAOS & 7 \\
\hline $\begin{array}{l}\text { Nabuurs-Franssen } \\
\text { et al, UK, USA } \\
\text { and Europe, } 2005 \text { [9] }\end{array}$ & $\begin{array}{l}\text { Randomised placebo- } \\
\text { controlled trial }\end{array}$ & $\begin{array}{l}\text { To assess whether ulcer healing improves } \\
\text { HRQOL (HRQOL as a secondary } \\
\text { outcome measure) }\end{array}$ & SF-36 & 13 \\
\hline $\begin{array}{l}\text { Willrich et al, } \\
\text { USA, } 2005 \text { [57] }\end{array}$ & Cross-sectional & $\begin{array}{l}\text { To assess HRQOL and depression in } \\
\text { DM patients with DFU, osteomyelitis, } \\
\text { Charcot arthropathy and LEA }\end{array}$ & SF-36 & 8 \\
\hline $\begin{array}{l}\text { Valensi et al, } \\
\text { France, 2005 [11] }\end{array}$ & Cross-sectional & $\begin{array}{l}\text { To compare the HRQOL of patients } \\
\text { with diabetes with and without DFU } \\
\text { to determine factors influencing } \\
\text { disease-specific HRQOL in DFU }\end{array}$ & $\begin{array}{l}\text { SF-36 } \\
\text { DFS }\end{array}$ & 13 \\
\hline $\begin{array}{l}\text { Vinik et al, } \\
\text { USA, } 2005 \text { [35] }\end{array}$ & Cross-sectional & $\begin{array}{l}\text { To validate and evaluate the Norfolk } \\
\text { QOL-DN tool }\end{array}$ & Norfolk QOL-DN & 9 \\
\hline
\end{tabular}


Table 1 (continued)

\begin{tabular}{|c|c|c|c|c|}
\hline Reference & Study design & Study aims & PROM used & $\begin{array}{l}\text { Quality } \\
\text { score }\end{array}$ \\
\hline $\begin{array}{l}\text { Currie et al, } \\
\text { UK, } 2006[20]\end{array}$ & Cost-utility & $\begin{array}{l}\text { To characterise symptom severity of DPN } \\
\text { in people with diabetes, correlating with } \\
\text { health-related utility and HRQOL }\end{array}$ & $\begin{array}{l}\text { Norfolk QOL-DN } \\
\text { SF-36 }\end{array}$ & 15 \\
\hline $\begin{array}{l}\text { Davies et al, } \\
\text { UK, } 2006[7]\end{array}$ & Cross-sectional & $\begin{array}{l}\text { To determine the prevalence and severity } \\
\text { of painful DPN and examine its } \\
\text { impact on HRQOL }\end{array}$ & NeuroQoL & 12 \\
\hline $\begin{array}{l}\text { Goodridge et al, } \\
\text { Canada, } 2006 \text { [58] }\end{array}$ & Cross-sectional & $\begin{array}{l}\text { To evaluate HRQOL in patients with } \\
\text { unhealed and healed DFUs }\end{array}$ & $\begin{array}{l}\text { CWIS } \\
\text { SF-12 }\end{array}$ & 12 \\
\hline $\begin{array}{l}\text { Ribu et al, } \\
\text { Norway, } 2006 \text { [15] }\end{array}$ & Cross-sectional & $\begin{array}{l}\text { To assess the prevalence and occurrence } \\
\text { of DFU pain on HRQOL using generic } \\
\text { and disease-specific PROMS }\end{array}$ & $\begin{array}{l}\text { SF-36 } \\
\text { DFS }\end{array}$ & 9 \\
\hline $\begin{array}{l}\text { Tarride et al, } \\
\text { Canada, } 2006 \text { [59] }\end{array}$ & Cost-utility & $\begin{array}{l}\text { To examine the } 12 \text { week cost-effectiveness } \\
\text { of pregabalin vs gabapentin, in DPN } \\
\text { and post-herpetic neuralgia }\end{array}$ & EQ-5D & 8 \\
\hline $\begin{array}{l}\text { Tolle et al, } \\
\text { Europe, } 2006[60]\end{array}$ & Cost-utility & $\begin{array}{l}\text { To determine patient burden of painful } \\
\text { DPN with respect to pain intensity, } \\
\text { patient functioning and to characterise } \\
\text { treatment patterns }\end{array}$ & EQ-5D & 12 \\
\hline $\begin{array}{l}\text { Casselini et al, } \\
\text { USA, } 2007 \text { [61] }\end{array}$ & $\begin{array}{l}\text { Randomised controlled } \\
\text { double-blind placebo- } \\
\text { controlled trial }\end{array}$ & $\begin{array}{l}\text { To investigate the effects of PKC- } \beta \\
\text { inhibitor ruboxistaurin on neurovascular } \\
\text { function and other measures of DPN } \\
\text { (HRQOL as a secondary outcome) }\end{array}$ & Norfolk QOL DN & 9 \\
\hline $\begin{array}{l}\text { Lewko et al, } \\
\text { Poland, 2007 [62] }\end{array}$ & Cross-sectional & $\begin{array}{l}\text { To determine the relationship between } \\
\text { HRQOL and degrees of acceptance } \\
\text { of those with and without DPN }\end{array}$ & SF-36 & 6 \\
\hline $\begin{array}{l}\text { Nelson and Little, } \\
\text { USA, } 2007 \text { [63] }\end{array}$ & Cross-sectional & $\begin{array}{l}\text { To evaluate changes in HRQOL after } \\
\text { multiple lower-extremity nerve } \\
\text { decompressions in DPN }\end{array}$ & Sf-36 & 4 \\
\hline $\begin{array}{l}\text { Rauck et al, } \\
\text { USA, } 2007 \text { [25] }\end{array}$ & Randomised controlled trial & $\begin{array}{l}\text { To evaluate effects of lacosamide on } \\
\text { painful DPN (HRQOL as a secondary } \\
\text { outcome measure) }\end{array}$ & SF-36 & 11 \\
\hline $\begin{array}{l}\text { Ribu et al, } \\
\text { Norway, } 2007 \text { [14] }\end{array}$ & Cross-sectional & $\begin{array}{l}\text { To describe HRQOL in those with DFU } \\
\text { compared with controls }\end{array}$ & SF-36 & 9 \\
\hline $\begin{array}{l}\text { Ribu et al, } \\
\text { Norway, } 2007 \text { [13] }\end{array}$ & Cross-sectional & $\begin{array}{l}\text { To describe socio-demographic variables, } \\
\text { clinical characteristics and treatment } \\
\text { factors in DFU and to explore their } \\
\text { associations with HRQOL }\end{array}$ & SF-36 & 9 \\
\hline $\begin{array}{l}\text { Armstrong et al, } \\
\text { USA, } 2008 \text { [24] }\end{array}$ & Randomised controlled trial & $\begin{array}{l}\text { To compare the HRQOL of patients } \\
\text { with diabetes with and without pressure } \\
\text { offloading modalities to heal DFU }\end{array}$ & SF-36 & 11 \\
\hline $\begin{array}{l}\text { Boutoille et al, } \\
\text { France, } 2008 \text { [45] }\end{array}$ & Retrospective case-control & $\begin{array}{l}\text { To evaluate the influence of amputation } \\
\text { for DFU on HRQOL }\end{array}$ & SF-36 & 10 \\
\hline $\begin{array}{l}\text { Happich et al, } \\
\text { Germany, } 2008 \text { [64] }\end{array}$ & Observational cost analysis & $\begin{array}{l}\text { To describe HRQOL, resource utilisation } \\
\text { and annual costs associated with DPN }\end{array}$ & $\begin{array}{l}\text { SF-12 } \\
\text { Norfolk QoL-DN }\end{array}$ & 10 \\
\hline $\begin{array}{l}\text { Huang et al, } \\
\text { Taiwan, } 2008 \text { [16] }\end{array}$ & Cross-sectional & $\begin{array}{l}\text { To compare generic and disease-specific } \\
\text { measures of HRQOL in the assessment } \\
\text { of patients with diabetes (regardless of } \\
\text { foot health) }\end{array}$ & $\begin{array}{l}\text { D-39 } \\
\text { SF-36 }\end{array}$ & 10 \\
\hline $\begin{array}{l}\text { Lavery et al, } \\
\text { USA, } 2008 \text { [65] }\end{array}$ & Randomised controlled trial & $\begin{array}{l}\text { To determine the efficacy of anodyne } \\
\text { monochromatic infrared photo energy } \\
\text { in home treatments on improving } \\
\text { peripheral sensation and HRQOL in } \\
\text { patients with DM (HRQOL as a secondary } \\
\text { outcome measure) }\end{array}$ & NeuroQoL & 7 \\
\hline $\begin{array}{l}\text { Lincoln et al, } \\
\text { UK, } 2008 \text { [66] }\end{array}$ & Randomised controlled trial & $\begin{array}{l}\text { To determine the effect of a foot care } \\
\text { education programme in the secondary } \\
\text { prevention of foot ulcers (assessing } \\
\text { HRQOL as a secondary outcome) }\end{array}$ & DFS & 10 \\
\hline $\begin{array}{l}\text { Ribu et al, } \\
\quad \text { Norway, } 2008[10]\end{array}$ & Longitudinal & $\begin{array}{l}\text { To assess temporal changes } \\
\text { in HRQOL }\end{array}$ & SF-36 & 10 \\
\hline
\end{tabular}


Table 1 (continued)

\begin{tabular}{|c|c|c|c|c|}
\hline Reference & Study design & Study aims & PROM used & $\begin{array}{l}\text { Quality } \\
\text { score }\end{array}$ \\
\hline $\begin{array}{l}\text { Sochocki et al, } \\
\text { Canada, } 2008 \text { [18] }\end{array}$ & Cross-sectional & $\begin{array}{l}\text { To evaluate HRQOL in patients with } \\
\text { Charcot arthropathy and identify } \\
\text { risk factors that contribute to poor } \\
\text { HRQOL }\end{array}$ & SF-36 & 8 \\
\hline $\begin{array}{l}\text { Vinik et al, } \\
\text { Germany, } 2008[36]\end{array}$ & Cross-sectional & $\begin{array}{l}\text { To evaluate the German version of } \\
\text { the Norfolk QOL-DN }\end{array}$ & Norfolk QOL-DN & 6 \\
\hline $\begin{array}{l}\text { Jeffcoate et al, } \\
\text { UK, } 2009 \text { [27] }\end{array}$ & Randomised controlled trial & $\begin{array}{l}\text { To compare the effectiveness and } \\
\text { cost-effectiveness of three dressing } \\
\text { products for DFU }\end{array}$ & $\begin{array}{l}\mathrm{SF}-36 \\
\mathrm{CWIS} \\
10 \mathrm{~cm} \text { VAS }\end{array}$ & 14 \\
\hline $\begin{array}{l}\text { Pakarinen et al, } \\
\text { Finland, } 2009 \text { [17] }\end{array}$ & Cross-sectional & $\begin{array}{l}\text { To evaluate the long-term effects of } \\
\text { diabetes-related Charcot foot }\end{array}$ & SF-36 & 10 \\
\hline $\begin{array}{l}\text { Rerkasem et al, } \\
\text { Thailand, 2009 [49] }\end{array}$ & Retrospective cohort & $\begin{array}{l}\text { To assess the HRQOL outcomes of } \\
\text { DFU patients who were involved in } \\
\text { a randomised controlled trial assessing } \\
\text { outcomes in management according } \\
\text { to a 'diabetic foot pathway' compared } \\
\text { with standard care pathways }\end{array}$ & SF-36 & 9 \\
\hline $\begin{array}{l}\text { Winkley et al, } \\
\text { UK, } 2009 \text { [42] }\end{array}$ & Prospective cohort & $\begin{array}{l}\text { To describe temporal changes in HRQOL } \\
\text { in patients with their first DFU over } \\
18 \text { months and its association with } \\
\text { adverse outcomes }\end{array}$ & SF-36 & 12 \\
\hline $\begin{array}{l}\text { Jaksa and Mahoney, } \\
\text { Canada, } 2010[19]\end{array}$ & Cross-sectional & To evaluate the CWIS in a DFU population & $\begin{array}{l}\text { CWIS } \\
\text { SF-36 }\end{array}$ & 9 \\
\hline $\begin{array}{l}\text { Mittlmeier et al, } \\
\text { USA, } 2010[67]\end{array}$ & Retrospective cohort & $\begin{array}{l}\text { To evaluate outcomes in primary surgical } \\
\text { management of Charcot joints }\end{array}$ & $\begin{array}{l}\text { AOFAS Ankle } \\
\text { Hindfoot Scale }\end{array}$ & 9 \\
\hline $\begin{array}{l}\text { Selvarajah et al, } \\
\text { UK, } 2010 \text { [22] }\end{array}$ & Randomised controlled trial & $\begin{array}{l}\text { To assess efficacy of Sativex (GW } \\
\text { Pharmaceuticals, Salisbury, UK), a } \\
\text { cannabis-based product, as adjuvant } \\
\text { treatment of painful DPN (HRQOL } \\
\text { as secondary outcome) }\end{array}$ & $\begin{array}{l}\text { EQ-5D } \\
\text { SF-36 } \\
10 \mathrm{~cm} \text { VAS }\end{array}$ & 7 \\
\hline $\begin{array}{l}\text { Swislocki et al, } \\
\text { USA, } 2010 \text { [23] }\end{array}$ & Randomised controlled trial & $\begin{array}{l}\text { To evaluate the photon stimulations } \\
\text { affect on pain and HRQOL in patients } \\
\text { with painful DPN (HRQOL as secondary } \\
\text { outcomes) }\end{array}$ & SF-36 & 6 \\
\hline
\end{tabular}

AAOS, American Academy of Orthopaedic Surgeons Musculoskeletal Outcomes Measure: Foot and Ankle; ADL, activities of daily living; AKA, above-knee amputation; BKA, below-knee amputation; DM, patients with diabetes mellitus; QWB-SA, Quality of Well Being Index - Self Administered; PKC- $\beta$, protein kinase $\mathrm{C} \beta$; T2DM, type 2 diabetes mellitus; TA, toe amputation; TMA, transmetatarsal amputation; VAS, visual analogue scale; WSQ, Walking and Walking Stairs Questionnaire

Excellence (NICE) have specified the EuroQOL 5D Health Utility Index (EQ-5D) as the preferred PROM for use in the UK [32].

Diabetic foot-specific PROMs PROMs specifically designed to assess diabetes-related foot problems include the DFS [12], NeuroQoL [31] and the Carrington foot questionnaire [33].

The DFS was developed using semi-structured interviews and focus groups of patients with DFUs and their care givers [12]. It has shown internal consistency, reliability, validity $[12]$ and sensitivity to wound severity $[11,15]$ and healing [15]. A shortened version, the DFS Short Form (DFS-SF) [34] showed similar robustness and sensitivity. The DFS-SF has statistically significant regression correlations to the DFS and SF-36 and, at only 29 questions, is a more 'userfriendly' tool for everyday clinical practice.
NeuroQoL was designed to assess HRQOL in patients with diabetes complicated by peripheral neuropathy and DFUs. It has been validated against the SF-12 to show construct validity and sensitivity to neuropathic symptoms, which the SF-12 (as a generic instrument) is unable to detect. Factor analyses have demonstrated internal consistency and its brevity makes it feasible and acceptable.

NeuroQoL has proven proficient in assessing the impact of advancing neuropathy on HRQOL. It is less useful in showing the relationship between DFU severity and HRQOL. This may reflect the tool's focus on neuropathic (as opposed to ulcerative) symptoms. It could also be a consequence of diminished nociceptive responses in patients with ulcers, reducing pain scores (and thus indicating better HRQOL). However, a well-designed UK cross-sectional population study (using NeuroQoL) disputes this theory; showing more 
Table 2 PROMs used in eligible studies

\begin{tabular}{|c|c|c|c|c|c|}
\hline Instrument & Type & Domains/subscales & Scoring system & Comment & $\begin{array}{l}\text { Studies } \\
\text { using } \\
\text { PROM }\end{array}$ \\
\hline $\begin{array}{l}\text { The Medical Outcomes Study 36-item } \\
\text { Short-Form Health Survey (SF-36) }\end{array}$ & Generic & $\begin{array}{l}36 \text { questions measuring eight conceptual } \\
\text { domains: } \\
\text { - physical functioning } \\
\text { - } \text { godily pain } \\
\text { - } \text { vitality } \\
\text { - } \text { social functioning } \\
\text { hele limitations due to physical } \\
\text { - role limitations due to emotional } \\
\text { problems } \\
\text { mental health }\end{array}$ & $\begin{array}{l}\text { Three key scores: } \\
\text { - overall HRQOL score } \\
\text { - mental component summary score } \\
\text { (MCS-36) } \\
\text { - } \quad \text { physical component summary score } \\
\text { (PCS-36) } \\
\text { Overall HRQOL score } 0-100 \\
\text { (0 indicating poorest HRQOL) }\end{array}$ & $\begin{array}{l}\text { Facilitates comparison with other } \\
\text { chronic diseases. } \\
\text { Can be converted into SF-6D } \\
\text { scores for health utility } \\
\text { evaluations. } \\
\text { Not specific to diabetes-related } \\
\text { foot disease. } \\
\text { The most frequently utilised tool. }\end{array}$ & $\begin{array}{l}{[8][9]} \\
{[10][11]} \\
{[12][13]} \\
{[14][15]} \\
{[16][17]} \\
{[18][20]} \\
{[22][23]} \\
{[24][25]} \\
{[26][27]} \\
{[40][41]} \\
{[42][45]} \\
{[48][49]} \\
{[52][62]} \\
{[63]}\end{array}$ \\
\hline $\begin{array}{l}\text { Research and Development } 36 \text {-item Form } \\
\text { (RAND-36) }\end{array}$ & Generic & Assesses the same domains as SF- 36 . & $\begin{array}{l}\text { As SF- } 36 \text { but differs in the recommended } \\
\text { scoring algorithm. }\end{array}$ & & [29] \\
\hline $\begin{array}{l}\text { The Medical Outcomes Study } 12 \text {-item } \\
\text { Short-Form Health Survey (SF-12) }\end{array}$ & Generic & $\begin{array}{l}\text { Abbreviated adaptation of SF- } 36.12 \\
\text { questions measuring the eight conceptual } \\
\text { domains of the SF- } 36 \text {. }\end{array}$ & $\begin{array}{l}\text { Overall HRQOL score } 0-100 \\
(0 \text { indicating poorest HRQOL) }\end{array}$ & $\begin{array}{l}\text { An abbreviated version of SF- } 36 \text {. } \\
\text { Its brevity lends its use to } \\
\text { condition-specific surveys that are } \\
\text { used in clinical trials. } \\
\text { When converted into SF-6D } \\
\text { scores can be used in economic } \\
\text { evaluation. }\end{array}$ & $\begin{array}{l}{[31]} \\
{[58]} \\
{[64]}\end{array}$ \\
\hline Sickness Impact Profile (SIP) & Generic & $\begin{array}{l}136 \text { questions assessing } 12 \text { categories of } \\
\text { everyday activities: } \\
\text { - } \text { sleep and rest } \\
\text { - } \text { emotional behaviour } \\
\text { - } \text { body care and movement } \\
\text { - } \text { mobility } \\
\text { - } \text { social interaction } \\
\text { - ambulation } \\
\text { - } \text { commertness behaviour } \\
\text { - } \text { work } \\
\text { - } \text { recreation and pastimes } \\
\text { eating }\end{array}$ & $\begin{array}{l}\text { Scores } 0-100 \\
\text { (Scores }>20 \text { associated with severe } \\
\text { disability) }\end{array}$ & $\begin{array}{l}\text { Known as a 'health status score' } \\
\text { rather than measure of HRQOL. } \\
\text { Infrequently used in the } \\
\text { evaluation of diabetes-related foot } \\
\text { disease. }\end{array}$ & {$[30]$} \\
\hline Nottingham Health Profile (NHP) & Generic & $\begin{array}{l}\text { Part I: } 38 \text { statements requiring yes } / \text { no } \\
\text { responses to six domains: } \\
\text { - } \quad \text { nergy } \\
\text { - } \text { pain } \\
\text { - } \text { physical mobility } \\
\text { - } \quad \text { social isolation } \\
\text { Part II: seven yes/no questions on daily } \\
\text { living problems. }\end{array}$ & $\begin{array}{l}\text { Parts can be used independently. } \\
\text { Scores } 0-100 \\
\text { (100 indicating poorest HRQOL) }\end{array}$ & $\begin{array}{l}\text { Well-validated tool but } \\
\text { infrequently used in diabetes- } \\
\text { related foot disease. }\end{array}$ & {$[28]$} \\
\hline Quality of Life Ladder (QOLL) & Summary & Life satisfaction marked on a scale. & $\begin{array}{l}\text { Scores } 0-10 \\
(0 \text { indicating poorest HRQOL) }\end{array}$ & $\begin{array}{l}\text { Quick, non-specific estimate of } \\
\text { HRQOL. }\end{array}$ & [33] \\
\hline $10 \mathrm{~cm}$ Visual analogue scale (VAS) & Summary & $\begin{array}{l}\text { Pain score/HRQOL score marked on a } \\
10 \mathrm{~cm} \text { scale. }\end{array}$ & $\begin{array}{l}\text { Scores } 0-100 \% \\
(0 \text { indicating poorest HRQOL) }\end{array}$ & $\begin{array}{l}\text { Quick, non-specific estimate of } \\
\text { HRQOL. } \\
\text { Subject to poor external } \\
\text { consistency. } \\
\text { Used within the EQ-5D. }\end{array}$ & $\begin{array}{l}{[22]} \\
{[27]} \\
{[51]} \\
{[53]}\end{array}$ \\
\hline $\begin{array}{l}\text { The Medical Outcomes Study 6D Short- } \\
\text { Form Health Utility Index (SF-6D) }\end{array}$ & Utility & $\begin{array}{l}\text { Based on an algorithm using a subset of } \\
11 \text { questions from the SF- } 36 \text {. }\end{array}$ & $\begin{array}{l}\text { Estimates a preference based single } \\
\text { summary score which can be used against an } \\
\text { index of measures. }\end{array}$ & $\begin{array}{l}\text { Provides a means for using the } \\
\text { SF-36 and SF-12 in economic } \\
\text { evaluation. } \\
\text { Allows the analyst to obtain } \\
\text { quality-adjusted life-years } \\
\text { (QALYs) for cost-utility analysis. } \\
\text { Better descriptive ability and } \\
\text { sensitivity to change than EQ-5D. }\end{array}$ & {$[27]$} \\
\hline
\end{tabular}


Table 2 (continued)

\begin{tabular}{|c|c|c|c|c|c|}
\hline & & & & $\begin{array}{l}\text { Defines } 18,000 \text { health states. } \\
\text { Infrequently used to evaluate } \\
\text { HRQOL in diabetes-related foot } \\
\text { disease. }\end{array}$ & \\
\hline $\begin{array}{l}\text { Quality of Well Being Index - Self } \\
\text { Administered (QWB-SA) }\end{array}$ & Utility & $\begin{array}{l}\text { Participants asked to identify } \\
\text { symptoms/problems that have affected } \\
\text { them over last } 3 \text { days from list of } 58 \\
\text { items based on three scales of } \\
\text { functioning: } \\
\text { - mobility } \\
\text { - physical activity } \\
\text { social activity }\end{array}$ & $\begin{array}{l}\text { Score } 0-10 \\
(0 \text { indicating poorest HRQOL) }\end{array}$ & $\begin{array}{l}\text { Used to create health utility } \\
\text { scores. } \\
\text { Infrequently used to evaluate } \\
\text { HRQOL in diabetes-related foot } \\
\text { disease. }\end{array}$ & [54] \\
\hline $\begin{array}{l}\text { EuroQOL 5D Health Utility Index } \\
\text { (EQ-5D) }\end{array}$ & Utility & $\begin{array}{l}\text { Five questions with three possible } \\
\text { answers for each }(1=\text { no problem, } 2= \\
\text { moderate problem, } 3=\text { severe problems }) \\
\text { on: } \\
\text { - mobility } \\
\text { - usual activities } \\
\text { - pain/discomfort } \\
\text { and } \\
\text { Completion of } 20 \mathrm{~cm} \text { visual analogue } \\
\text { scale. } \\
\text { and } \\
\text { Single question on current health state: Is } \\
\text { it worse/same/better than } 1 \text { year } \\
\text { previous? }\end{array}$ & $\begin{array}{l}\text { Produces 'health state' profile comprising of } \\
\text { a single summary score created using a } \\
\text { formula which weighs the different domains, } \\
\text { based on EQ-5D scores from the general } \\
\text { population. } \\
\text { Numeric index generated from }-0.594 \text { to } 1 \text {. } \\
\text { (Score } 0 \text { represents no quality of life; scores } \\
<0 \text { represent states perceived by the } \\
\text { respondent to be worse than death) }\end{array}$ & $\begin{array}{l}\text { The five dimensions assessed can } \\
\text { be transcribed into } 243 \text { possible } \\
\text { health states. } \\
\text { Designed as research/health } \\
\text { utility tool - not recommended } \\
\text { for use in routine clinical practice. } \\
\text { Can generate QALYs from VAS. } \\
\text { Relies on ratings from the general } \\
\text { public to define 'normality' [ } 68 \text { ]. } \\
\text { Recommended for use in the UK } \\
\text { by NICE. }\end{array}$ & $\begin{array}{l}{[20]} \\
{[22]} \\
{[44]} \\
{[60]}\end{array}$ \\
\hline Barthel Index & $\begin{array}{l}\text { Dimension- } \\
\text { specific }\end{array}$ & Ten questions on activities of daily living. & $\begin{array}{l}\text { Score } 0-20 \\
(20 \text { indicates normality) }\end{array}$ & $\begin{array}{l}\text { Infrequently used to evaluate } \\
\text { HRQOL in diabetes-related foot } \\
\text { disease. }\end{array}$ & [29] \\
\hline $\begin{array}{l}\text { Walking and Walking Stairs } \\
\text { Questionnaire (WSQ) }\end{array}$ & $\begin{array}{l}\text { Dimension- } \\
\text { specific }\end{array}$ & $\begin{array}{l}62 \text { questions subdivided into four } \\
\text { hierarchical scales. }\end{array}$ & $\begin{array}{l}\text { Scores } 0-100 \\
\text { ( } 0 \text { indicating poorest mobility) }\end{array}$ & $\begin{array}{l}\text { Not a global assessment of } \\
\text { HRQOL. } \\
\text { Infrequently used to evaluate } \\
\text { HRQOL in diabetes-related foot } \\
\text { disease. }\end{array}$ & [29] \\
\hline $\begin{array}{l}\text { American Academy of Orthopaedic } \\
\text { Surgeons - Diabetic Foot Questionnaire } \\
\text { (AAOS-DFQ) }\end{array}$ & $\begin{array}{l}\text { Disease- } \\
\text { specific }\end{array}$ & $\begin{array}{l}\text { 66 question tool in five sub-sections: } \\
\text { - } \text { demographics } \\
\text { - gealth conditions } \\
\text { - } \text { foot problems } \\
\text { assessiabetes and foot care } \\
\text { - general health } \\
\text { - } \text { physicality } \\
\text { - } \text { worry } \\
\text { - } \text { foot status } \\
\text { care }\end{array}$ & $\begin{array}{l}\text { Numerous outcome measure scales: } \\
\text { Scores } 0-100 \\
(0 \text { indicating poorest HRQOL) }\end{array}$ & $\begin{array}{l}\text { Made from pre-validated } \\
\text { instruments but, as a whole, } \\
\text { limited validation of AAOS-DFQ. } \\
\text { Specific but cumbersome scoring } \\
\text { scales. } \\
\text { Infrequently used to evaluate } \\
\text { HRQOL in diabetes-related foot } \\
\text { disease. }\end{array}$ & [55] \\
\hline Diabetes 39 (D-39) & $\begin{array}{l}\text { Disease- } \\
\text { specific }\end{array}$ & 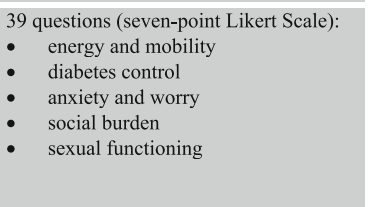 & $\begin{array}{l}\text { Subscale scores generated with higher scores } \\
\text { reflecting poorer HRQOL. } \\
\text { Summary score created from subscale scores. }\end{array}$ & $\begin{array}{l}\text { For HRQOL assessment in T1/T2 } \\
\text { diabetes mellitus. } \\
\text { Not specific to foot pathology. } \\
\text { Infrequently used to evaluate } \\
\text { HRQOL in diabetes-related foot } \\
\text { disease. }\end{array}$ & [16] \\
\hline Cardiff Wound Impact Schedule (CWIS) & $\begin{array}{l}\text { Disease- } \\
\text { specific }\end{array}$ & $\begin{array}{l}47 \text { questions divided into four domains: } \\
\text { - } \quad \text { well-being } \\
\text { - } \quad \text { social life } \\
\text { overall quality of life }\end{array}$ & $\begin{array}{l}\text { Scores } 0-100 \\
(0 \text { indicating the poorest } \mathrm{HRQOL})\end{array}$ & $\begin{array}{l}\text { For all chronic wounds. } \\
\text { Shows sensitivity to wound } \\
\text { healing in RCT evaluating types } \\
\text { of dressings for DFU [27]. } \\
\text { Lacks sensitivity to ulcer severity } \\
\text { [8]. }\end{array}$ & $\begin{array}{l}{[8]} \\
{[19]} \\
{[27]} \\
{[58]}\end{array}$ \\
\hline $\begin{array}{l}\text { Norfolk Quality of Life in Diabetic } \\
\text { Peripheral Neuropathy Questionnaire } \\
\text { (Norfolk QoL DN) }\end{array}$ & $\begin{array}{l}\text { Disease- } \\
\text { specific }\end{array}$ & $\begin{array}{l}\text { 47 questions grouped into: } \\
\text { - } \quad \text { small fibre function } \\
\text { - } \quad \text { autonomic function } \\
\text { - } \quad \text { symptoms } \\
\text { activities of daily living }\end{array}$ & $\begin{array}{l}\text { Score } 0-100 \% \\
(0 \text { indicating best HRQOL) }\end{array}$ & $\begin{array}{l}\text { Designed as a 'fibre-specific' tool } \\
\text { to assess all aspects of DPN. } \\
\text { Not specific to foot disease. }\end{array}$ & $\begin{array}{l}{[20]} \\
{[35]} \\
{[36]} \\
{[61]} \\
{[64]}\end{array}$ \\
\hline
\end{tabular}


Table 2 (continued)

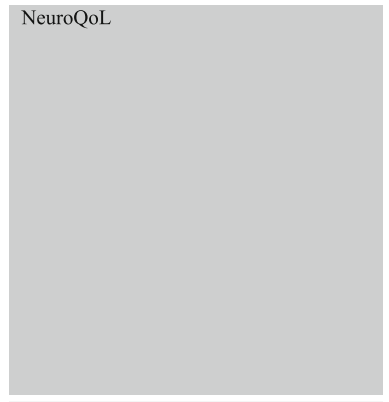

Foot Questionnaire

Diabetes Foot Ulcer Scale (DFS)

Diabetes Foot Ulcer Scale-Short Form (DFS-SF)

American Academy of Foot and Ankle Surgeons - Ankle/Hindfoot Scale (AOFAS-Ankle/Hindfoot Scale)

American Academy of Orthopaedic
Surgeons Musculoskeletal Outcomes
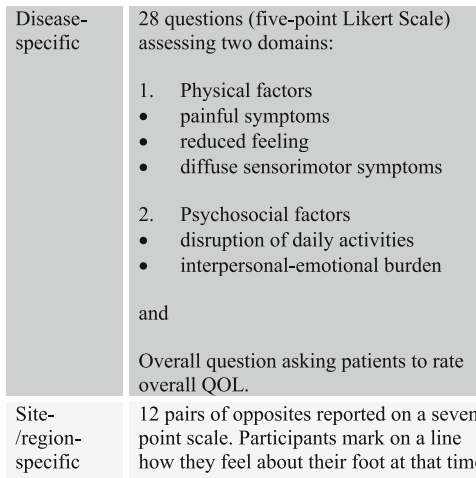

assessing two domains:

1. Physical factors

- painful symptoms

- reduced feeling

diffuse sensorimotor symptoms

2. Psychosocial factors

- interpersonal-emotional burden

and

Overall question asking patients to rate overall QOL. point scale. Participants mark on a line

how they feel about their foot at that time.

Site-
/region-
specific

Site-
/region-
specific

58 questions assessing factors specific to DFUs in 15 subscales:

- leisure

- physical health

- daily life

- dependence

- family and friends

- treatment compliance

- positive relationship

- financial burden

- side effects

- diet

- compliance

- medical complications

- satisfaction

29 questions based on six subscales:

- leisure

- physical health

- dependence/daily life

- negative emotions

- worry about ulcer/feet

- impact of ulcer care Measure: Foot and Ankle (AAOS)

Site-

/region-

Clinical based outcomes from nine

questions on three subscales:

- pain

- function

- alignment

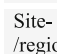

Five subscales each containing nine

/region-

items:

specific
- disruption of daily activities

12 pairs of opposites reported on a seven

Two scale scores: physical symptom and psychosocial functioning.

Overall HRQOL measured by one-item measure from NeuroQoL.

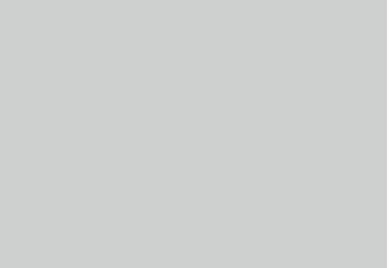

Higher scores indicating more positive attitude towards feet.

Scores $0-100$

(0 indicating poorer HRQOL)

Assessed against SF-36: assumed superior as more reliable in

discriminating between healed and current DFU [10, 12-14].

[11]

[12]

$15]$

[66]

Scores 0-100

Well validated against DFS.

[69]

(0 indicating poorer HRQOL)

Brevity enhances acceptability.

Produces outcome measure scales. All scales with scores from $0-100$ :

- co-morbidity scale

- individual co-morbidity subscales

- physical health and pain (aka SF-36)

- treatment expectations

- satisfaction with symptoms

- global foot and ankle scale (GFAS)

- shoe comfort scale (SCS)

Overall scores 0-100

Subjective scores of pain and
function provided by the patien function provided by the patient
Objective scores based on the surgeon's physical examination of the patient, making it not a 'true' PROM.

Infrequently used to evaluate HRQOL in diabetes-related foot disease.

\section{7]}

65]

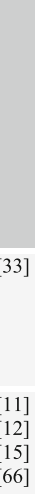

[33]

General health system includes SF-36 item set.

[40]

[56]

numerous scales.

Not validated against any other HRQOL tools.

- appearance

- functional capacities

- radiographic evaluation

musculoskeletal severe neuropathy to be associated with a higher prevalence of pain and a poorer HRQOL [7]. NeuroQoL's poor sensitivity to DFUs may therefore be related to its failure to assess ulcer-related therapies (e.g. non-weight-bearing regimens, dressing changes and antibiotic therapy).

The Norfolk Quality of Life in Diabetic Neuropathy Questionnaire (Norfolk QoL-DN) was designed to assess all aspects of diabetes-related neuropathic disease. It is intended for use as a diagnostic aide as well as for disease monitoring and treatment evaluation [20, 35]. Despite robust validation, the Norfolk QoL-DN [35, 36] lacks specificity for peripheral neuropathy, limiting its use in assessing the impact of diabetes-related foot disease.

Disease-specific tools for diabetes-related peripheral neuropathy (DPN) have shown sensitivity to symptom severity but no attempts have been made to evaluate their 


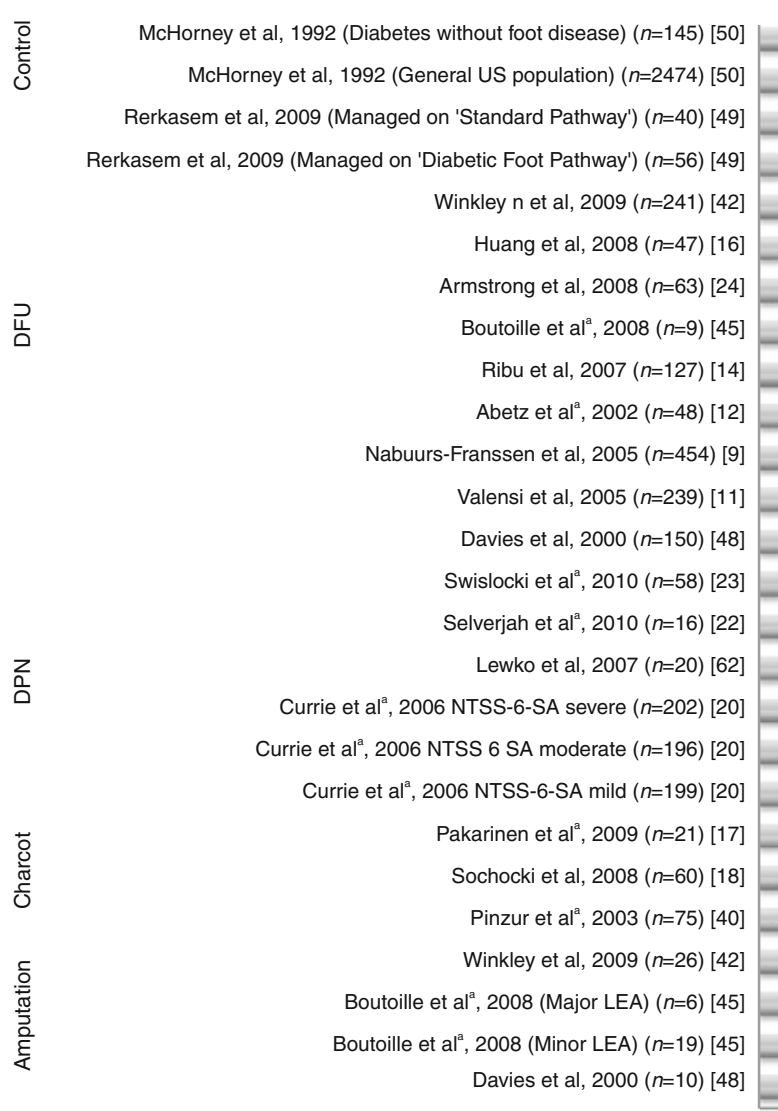

Fig. 2 Comparison of SF-36 physical component scores (PCS, dark grey bars) and mental component scores (MCS, light grey bars) from studies using the SF-36 to record HRQOL in diabetes-related foot disease. Scores compared to those from patients with diabetes without foot disease and the general US population [50]. Scores as stated in

efficacy in assessing temporal changes in HRQOL in individuals with DPN. As a result their use in disease monitoring is currently limited.

Wound-specific PROMs The CWIS has validity in assessing chronic wounds but is not specific to DFUs [8, 19]. Evaluation alongside the SF-36 showed significant correlations in all domains [8, 19] but sensitivity to severity of DFUs was lacking when CWIS HRQOL values were compared against ulcer severity (as determined by the University of Texas Wound Classification system) [19]. The CWIS is able to discriminate between healed and unhealed ulcers [8, 27]

Combined generic and disease-specific PROMs Combining generic and disease-specific PROMs produces more useful information on outcomes [4]. Different measures provide complementary evidence, with disease-specific tools offering specific clinical information and reflecting treatment effects and generic measures collecting information more transferrable to the service provider and highlighting unforeseen intervention effects. There are no 'combined PROMs' in use in diabetes-related foot disease.

The impact of foot complications on HRQOL in patients with diabetes

Foot monitoring and podiatry Individuals with diabetes without foot disease have a lower HRQOL compared with the general population (Fig. 2) [7, 8, 11, 12, 14, 28, 29, 33, $35,36]$. This may relate to the general lifestyle/complications of diabetes but may also reflect the commitment needed to preserve foot health. Patient focus groups have shown that preventative foot care practices (regular visits to the podiatrist, having to wear restrictive footwear, daily foot care regimens and restrictions on activities, etc) negatively impacts HRQOL [8, 37].

$D P N$ DPN may be asymptomatic but when painful impacts on HRQOL. Functional problems (disturbed balance; reduced foot sensation; disturbed sleep; limitations in footwear) and 


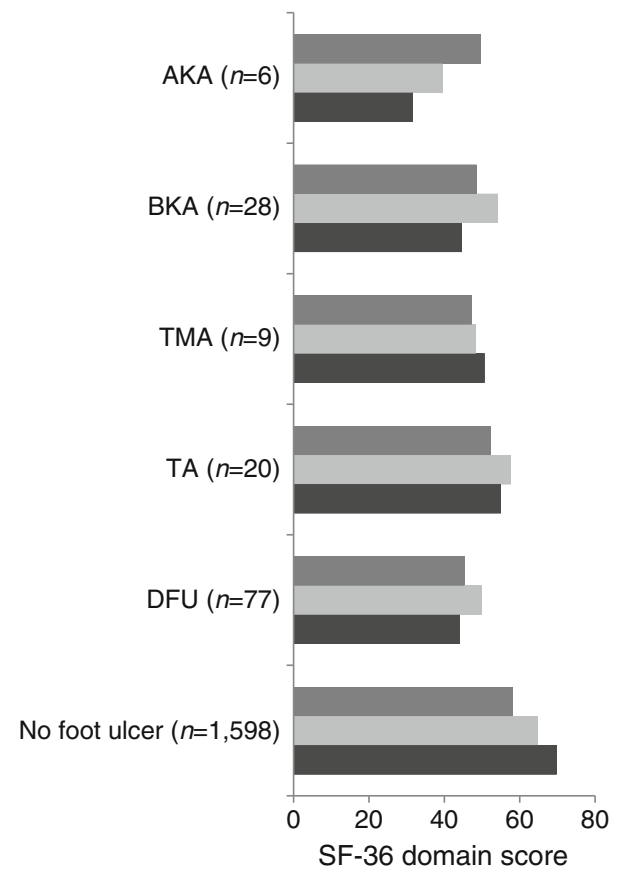

Fig. 3 Comparison of mean SF-36 domain scores in patients with type 2 diabetes and DFU undergoing amputation vs medical management. Scores compared with patients with diabetes without foot disease [41]. Scores range from 0 to 100 with a score of 0 reflecting poorest life HRQOL. Mid-grey bars, General Perception of Health; light grey bars, Pain Score; dark grey bars, Physical Functioning. AKA, above-knee amputation; BKA, below-knee amputation; TMA, transmetatarsal amputation; TA, toe amputation

psychological fears of advancing disease, ulceration and amputation often exist together. DPN is difficult to study in terms of impact on HRQOL as the classical view is that less advanced neuropathy is associated with more pain [38]. In advanced foot disease (e.g. ulceration), it is difficult to determine the exact impact of neuropathy in isolation.

Ulceration Ulcer healing has a positive impact on HRQOL scores whilst persisting ulcers have a progressively negative effect on life quality [8-10, 12]. HRQOL scores in patients who have undergone successful minor amputation for DFUs are significantly superior to those with persisting ulcers [30, 33] (although definitions of successful amputation are vague). Those who undergo major lower extremity amputation (LEA) have worse HRQOL scores than those with active DFUs [30, 33].

One study assessing variables that determine HRQOL in DFUs showed: presence of infection, co-existing peripheral arterial disease and ulcer size to be the most important [14]. When evaluating the influence of pain on HRQOL in DFUs, the same group reported that larger persisting ulcers $(>5 \mathrm{~cm})$ were less painful than smaller ulcers of shorter existence [15], but were associated with poorer HRQOL due to 'non pain related' factors. Indeed focus groups have found that HRQOL in DFUs most closely relate to the impact of treatments (regular dressing changes, poorer mobility caused by non weight bearing regimens, prolonged antibiotic therapy), anxieties around possibilities of future amputation, financial losses secondary to medical incapacity and the day to day disruption on social and family life rather than the ulcer size or duration [39].

Charcot arthropathy Few studies formally assessed HRQOL in patients with diabetes and Charcot disease [17, 18, 40]. Of those studies that identified Charcot arthropathy as a separate subgroup, it was suggested (using the American Academy of Orthopaedic Surgeons - Diabetic Foot Questionnaire [AAOS $-\mathrm{DFQ}]$ and SF-36) that the health status in these patients was comparable to that following minor LEA [40]. However these studies were small and a more detailed analysis of a broader spectrum of patients at different stages of Charcot arthropathy is required.

Amputation Outcomes in amputation have focused on functional status and mobility rather than HRQOL. A large cost-utility analysis performed in USA used three components of the SF-36 to assess HRQOL in patients with diabetes [41]. Those with active ulcers had significantly lower HRQOL scores for 'physical functioning' than those who had undergone successful toe or transmetatarsal amputations. Physical functioning in below knee amputation was no different to that in DFUs, but above knee amputation scores were worse (Fig. 4). Despite the large overall size of this cross-sectional analysis, the subgroups of interest were small and amputation groups poorly representative. Only patients who had undergone successful operations were included in this study (although 'success' was poorly defined), with no account for amputation related morbidity and mortality.

In the UK, a prospective cohort study used the SF-36 to chart HRQOL outcomes in patients with their first

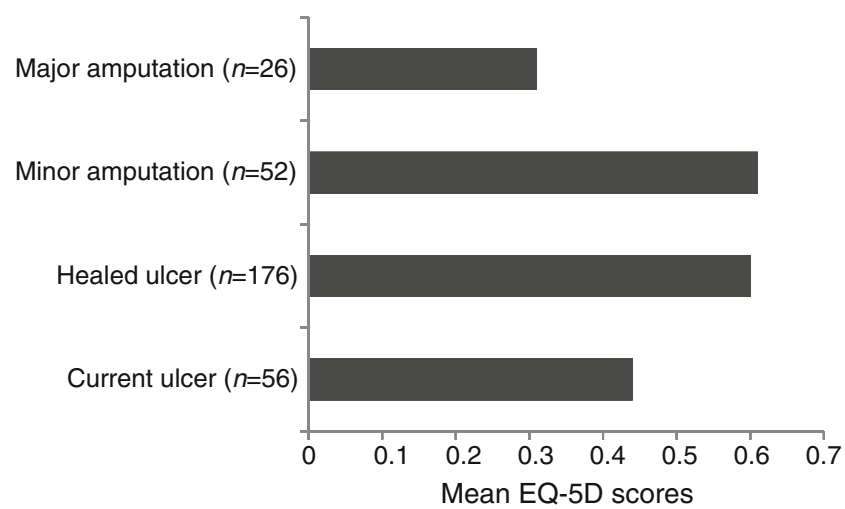

Fig. 4 Mean EQ-5D scores for patients with active ulceration/healed ulcers/minor amputation/major amputation. Possible scores range from -0.594 to 1 . A score of 0 represents no life quality; scores $<0$ reflect a perceived life quality worse than death; a score of 1 indicates best possible life quality $[43,44]$ 
diagnosis of DFUs. No significant deterioration in HRQOL scores was found (when adjusted for confounders) in those who went on to amputation [42]. Similarly, observational studies in Sweden $[43,44]$ and France [45], using the EQ$5 \mathrm{D}$ and SF-36, respectively, found (with the exception of major amputation, where scores were considerably lower) poorer HRQOL scores in those with active DFUs compared with patients who had undergone successful minor amputations. The Swedish group showed no difference in scores for minor amputation and primary ulcer healing (Fig. 4). Two other small observational studies [30, 33] have shown similar patterns.

Of key importance, all the studies identified that evaluate HRQOL in patients post amputation were of poor quality with small, highly selected patient groups (i.e. well healed rather than amputation stumps with complications).

Environment, delivery and modality of care A supportive multi-disciplinary team (MDT) for diabetes care is associated with improved self-management and health-related outcomes [46-48]. Using generic and disease-specific PROMs (SF-36 and DFS), a French observational study [11] found better HRQOL outcomes for patients managed in tertiary centres, with less deterioration in physical health scores, less irritation due to ulcer appearance, shorter durations of foot ulcer care, greater closeness with partners and friends and greater satisfaction with overall medical care. These results were echoed by patients cared for by a devoted MDT in Thailand [49].

\section{Discussion}

Generic, diabetes foot-specific, utility, complication-specific, summary, site-specific and combination PROMs all have validity in measuring HRQOL in patients with diabetesrelated foot disease. However, each has its limitations and none can be considered a suitable tool in every study or complication setting. Of the generic tools, the SF-36 shows sensitivity to foot disease and has been used most frequently but lacks NICE approval for use in utility studies (who favour the EQ-5D). Of the disease-specific tools, the DFS and NeuroQoL are the most validated, but no studies have compared them simultaneously and, as their titles suggest, they fail to encompass the full spectrum of diabetes-related foot disease. The CWIS shows promise in assessing HRQOL in active ulceration, but is non-specific for DFUs and may fail to capture aspects of this disease. Using a combination of generic and disease-specific PROMs should produce the most meaningful outcomes, but as indicated by the poor response rate in one randomised trial, the use of two instruments (e.g. CWIS and SF-36) may be cumbersome and unfeasible in clinical practice [27].
Generic HRQOL tools are limited in their abilities in identifying the factors reducing HRQOL (for example, a low score on 'role performance' may result from retinopathy rather than foot disease). Their advantage is that they can be compared against pre-existing figures from the general population and translated into cost-utility analysis making these tools more amenable to the research setting.

Disease-specific tools (DFS, NeuroQoL) offer greater insight into specific issues impairing health status. They show greater sensitivity to changing foot health/disease severity and are subject to fewer confounders, offering greater insights into lifestyle factors that may be improved by the MDT. Limitations include validation in smaller numbers of studies, exclusivity to disease state (cannot be given to a disease free control group) and narrow focus (they may miss unexpected aspects of impaired HRQOL, e.g. gastrointestinal side effects from antibiotics used to treat osteomyelitis that would not exist with surgical management). In contrast, these tools offer more use in the clinical setting for disease monitoring.

The quality of studies available was variable. The assessment of test-retest reliability and use of comparable HRQOL tools to assess construct validity of PROMs was often lacking and should be encouraged when validating any PROM. The 'quality score' used in this review is a gross estimate of 'quality' pertaining to the correct use of a PROM [3]. However, a well designed RCT that uses a single PROM as a secondary outcome measure may have a poor quality score due to a number of issues such as an ungeneralisable patient group, lack of re-test validation and lack of discussion of HRQOL domains, etc. The score is therefore more useful in observational studies designed to evaluate PROMs.

HRQOL PROMs have shown the negative impact of advancing foot disease on quality of life. Where uncertainty lies is in outcomes post LEA, where only a small number of poorly generalisable studies have assessed patient reported HRQOL using PROMs [7, 30, 33, 41-43, 45]. The suggestions from these studies (that HRQOL after successful minor amputation is superior to that of active ulceration) could form a large paradigm shift in clinical approach and management of DFUs. However, patient HRQOL after unsuccessful or complicated LEA is a neglected area of study and given that amputations are associated with significant peri-operative and late morbidity, more work in this area is required before any direct conclusions can be made.

Studies indicate that patient-reported HRQOL in DFUs is superior in patients managed by an MDT [11, 49]. There is no data to suggest whether MDT management would improve HRQOL in patients with less severe foot disease.

Preserving HRQOL in patients with diabetes-related foot disease is of high importance and should be measured accurately in order to guide appropriate management of these 
patients. Using HRQOL PROMs can offer valid insights into this complex and ever increasing disease; shaping service provision and ensuring cost effective patient care.

This review has demonstrated that a number of tools exist to assess HRQOL in patients with foot-related complications of diabetes. There is no one ideal PROM from which to assess HRQOL and each tool has its limitations. Clinicians and researchers should be aware of these limitations before implementation in individual settings.

Contribution statement All authors were involved in the conception of the paper or analysis and interpretation of data; the drafting or revision of the article; and the review of the final version for publication.

Duality of interest The authors declare that there is no duality of interest associated with this manuscript.

\section{References}

1. Hinchliffe RJ, Valk GD, Apelqvist J et al (2008) A systematic review of the effectiveness of interventions to enhance the healing of chronic ulcers of the foot in diabetes. Diabetes Metab Res Rev 24(Suppl 1):S119-S144

2. Darzi A (2008) Quality and the NHS next stage review. Lancet 371:1563-1564

3. Cornish D, Holterhues C, van de Poll-Franse LV, Coebergh JW, Nijsten T (2009) A systematic review of health-related quality of life in cutaneous melanoma. Ann Oncol 20(Suppl 6):vi51-vi58

4. Fitzpatrick R, Davey C, Buxton MJ, Jones DR (1998) Evaluating patient-based outcome measures for use in clinical trials. Health Technol Assess 2:i-iv, 1-74

5. Liberati A, Altman DG, Tetzlaff J et al (2009) The PRISMA statement for reporting systematic reviews and meta-analyses of studies that evaluate health care interventions: explanation and elaboration. J Clin Epidemiol 62:e1-e34

6. Moher D, Liberati A, Tetzlaff J, Altman DG (2009) Preferred reporting items for systematic reviews and meta-analyses: the PRISMA statement. J Clin Epidemiol 62:1006-1012

7. Davies M, Brophy S, Williams R, Taylor A (2006) The prevalence, severity, and impact of painful diabetic peripheral neuropathy in type 2 diabetes. Diabetes Care 29:1518-1522

8. Price P, Harding K (2004) Cardiff Wound Impact Schedule: the development of a condition-specific questionnaire to assess health-related quality of life in patients with chronic wounds of the lower limb. Int Wound $\mathrm{J}$ 1:10-17

9. Nabuurs-Franssen MH, Huijberts MS, Nieuwenhuijzen Kruseman AC, Willems J, Schaper NC (2005) Health-related quality of life of diabetic foot ulcer patients and their caregivers. Diabetologia 48:1906-1910

10. Ribu L, Birkeland K, Hanestad BR, Moum T, Rustoen T (2008) A longitudinal study of patients with diabetes and foot ulcers and their health-related quality of life: wound healing and quality-oflife changes. J Diabetes Complications 22:400-407

11. Valensi P, Girod I, Baron F, Moreau-Defarges T, Guillon P (2005) Quality of life and clinical correlates in patients with diabetic foot ulcers. Diabetes Metab 31:263-271

12. Abetz L, Sutton M, Brady L, McNulty P, Gagnon D (2002) The Diabetic Foot Ulcer Scale (DFS): a quality of life instrument for use in clinical trials. Pract Diabetes Int 19:167-175
13. Ribu L, Hanestad BR, Moum T, Birkeland K, Rustoen T (2007) Health-related quality of life among patients with diabetes and foot ulcers: association with demographic and clinical characteristics. J Diabetes Complications 21:227-236

14. Ribu L, Hanestad BR, Moum T, Birkeland K, Rustoen T (2007) A comparison of the health-related quality of life in patients with diabetic foot ulcers, with a diabetes group and a nondiabetes group from the general population. Qual Life Res 16:179-189

15. Ribu L, Rustoen T, Birkeland K, Hanestad BR, Paul SM, Miaskowski C (2006) The prevalence and occurrence of diabetic foot ulcer pain and its impact on health-related quality of life. $\mathrm{J}$ Pain 7:290-299

16. Huang IC, Hwang CC, Wu MY, Lin W, Leite W, Wu AW (2008) Diabetes-specific or generic measures for health-related quality of life? Evidence from psychometric validation of the D-39 and SF36. Value Health 11:450-461

17. Pakarinen TK, Laine HJ, Maenpaa H, Mattila P, Lahtela J (2009) Long-term outcome and quality of life in patients with Charcot foot. Foot Ankle Surg 15:187-191

18. Sochocki MP, Verity S, Atherton PJ et al (2008) Health related quality of life in patients with Charcot arthropathy of the foot and ankle. Foot Ankle Surg 14:11-15

19. Jaksa PJ, Mahoney JL (2010) Quality of life in patients with diabetic foot ulcers: validation of the Cardiff Wound Impact Schedule in a Canadian population. Int Wound J 7(6):502-507

20. Currie CJ, Poole CD, Woehl A et al (2006) The health-related utility and health-related quality of life of hospital-treated subjects with type 1 or type 2 diabetes with particular reference to differing severity of peripheral neuropathy. Diabetologia 49:2272-2280

21. Ware JE Jr, Kosinski M, Bjorner JB, Turner-Bowker DM, Gandek B, Maruish ME (2007) User's manual for the SF-36v2 health survey, 2nd edn. QualityMetric, Inc, Lincoln

22. Selvarajah D, Gandhi R, Emery CJ, Tesfaye S (2010) Randomized placebo-controlled double-blind clinical trial of cannabis-based medicinal product (Sativex) in painful diabetic neuropathy: depression is a major confounding factor. Diabetes Care 33:128130

23. Swislocki A, Orth M, Bales M et al (2010) A randomized clinical trial of the effectiveness of photon stimulation on pain, sensation, and quality of life in patients with diabetic peripheral neuropathy. J Pain Symptom Manage 39:88-99

24. Armstrong DG, Lavery LA, Wrobel JS, Vileikyte L (2008) Quality of life in healing diabetic wounds: does the end justify the means? J Foot Ankle Surg 47:278-282

25. Rauck RL, Shaibani A, Biton V, Simpson J, Koch B (2007) Lacosamide in painful diabetic peripheral neuropathy: a phase 2 double-blind placebo-controlled study. Clin J Pain 23:150-158

26. Rosenstock J, Tuchman M, LaMoreaux L, Sharma U (2004) Pregabalin for the treatment of painful diabetic peripheral neuropathy: a double-blind, placebo-controlled trial. Pain 110:628-638

27. Jeffcoate WJ, Price PE, Phillips CJ et al (2009) Randomised controlled trial of the use of three dressing preparations in the management of chronic ulceration of the foot in diabetes. Health Technol Assess 13:1-86, iii-iv

28. Benbow SJ, Wallymahmed ME, MacFarlane IA (1998) Diabetic peripheral neuropathy and quality of life. QJM 91:733-737

29. Meijer JW, Trip J, Jaegers SM et al (2001) Quality of life in patients with diabetic foot ulcers. Disabil Rehabil 23:336-340

30. Peters EJ, Childs MR, Wunderlich RP, Harkless LB, Armstrong DG, Lavery LA (2001) Functional status of persons with diabetesrelated lower-extremity amputations. Diabetes Care 24:1799-1804

31. Vileikyte L, Peyrot M, Bundy C et al (2003) The development and validation of a neuropathy- and foot ulcer-specific quality of life instrument. Diabetes Care 26:2549-2555

32. National Institute for Health and Clinical Excellence (2008) Guide to the methods of technology appraisal, 2008. NICE, London 
33. Carrington AL, Mawdsley SK, Morley M, Kincey J, Boulton AJ (1996) Psychological status of diabetic people with or without lower limb disability. Diabetes Res Clin Pract 32:19-25

34. Belury MA, Mahon A, Banni S (2003) The conjugated linoleic acid (CLA) isomer, t10c12-CLA, is inversely associated with changes in body weight and serum leptin in subjects with type 2 diabetes mellitus. J Nutr 133:257S-260S

35. Vinik EJ, Hayes RP, Oglesby A et al (2005) The development and validation of the Norfolk QOL-DN, a new measure of patients' perception of the effects of diabetes and diabetic neuropathy. Diabetes Technol Ther 7:497-508

36. Vinik EJ, Paulson JF, Ford-Molvik SL, Vinik AI (2008) Germantranslated Norfolk quality of life (QOL-DN) identifies the same factors as the English version of the tool and discriminates different levels of neuropathy severity. J Diabetes Sci Technol 2:1075-1086

37. Hjelm K, Nyberg P, Apelqvist J (2002) Gender influences beliefs about health and illness in diabetic subjects with severe foot lesions. J Adv Nurs 40:673-684

38. Duby JJ, Campbell RK, Setter SM, White JR, Rasmussen KA (2004) Diabetic neuropathy: an intensive review. Am J Health Syst Pharm 61:160-173

39. Brod M (1998) Quality of life issues in patients with diabetes and lower extremity ulcers: patients and care givers. Qual Life Res 7:365-372

40. Pinzur MS, Evans A (2003) Health-related quality of life in patients with Charcot foot. Am J Orthop (Belle Mead NJ) 32:492-496

41. Eckman MH, Greenfield S, Mackey WC et al (1995) Foot infections in diabetic patients. Decision and cost-effectiveness analyses. JAMA 273:712-720

42. Winkley K, Stahl D, Chalder T, Edmonds ME, Ismail K (2009) Quality of life in people with their first diabetic foot ulcer: a prospective cohort study. J Am Podiatr Med Assoc 99:406-414

43. Ragnarson Tennvall G, Apelqvist J (2000) Health-related quality of life in patients with diabetes mellitus and foot ulcers. J Diabetes Complicat 14:235-241

44. Tennvall GR, Apelqvist J, Eneroth M (2000) Costs of deep foot infections in patients with diabetes mellitus. PharmacoEconomics 18:225-238

45. Boutoille D, Feraille A, Maulaz D, Krempf M (2008) Quality of life with diabetes-associated foot complications: comparison between lower-limb amputation and chronic foot ulceration. Foot Ankle Int 29:1074-1078

46. Tang TS, Brown MB, Funnell MM, Anderson RM (2008) Social support, quality of life, and self-care behaviors among African Americans with type 2 diabetes. Diabetes Educ 34:266-276

47. Garay-Sevilla ME, Nava LE, Malacara JM et al (1995) Adherence to treatment and social support in patients with non-insulin dependent diabetes mellitus. J Diabetes Complications 9:81-86

48. Davies S, Gibby O, Phillips C, Price P, Tyrrell W (2000) The health status of diabetic patients receiving orthotic therapy. Qual Life Res 9:233-240

49. Rerkasem K, Kosachunhanun N, Tongprasert S, Guntawongwan $\mathrm{K}$ (2009) A multidisciplinary diabetic foot protocol at Chiang Mai University Hospital: cost and quality of life. Int J Low Extrem Wounds 8:153-156

50. McHorney CA, Ware JE Jr, Rogers W, Raczek AE, Lu JF (1992) The validity and relative precision of MOS short- and long-form health status scales and Dartmouth COOP charts. Results from the Medical Outcomes Study. Med Care 30(5 Suppl):MS253-MS265

51. Armstrong DG, Lavery LA, Fleischli JG, Gilham KA (1997) Is electrical stimulation effective in reducing neuropathic pain in patients with diabetes? J Foot Ankle Surg 36:260-263

52. Backonja M, Beydoun A, Edwards KR et al (1998) Gabapentin for the symptomatic treatment of painful neuropathy in patients with diabetes mellitus: a randomized controlled trial. JAMA 280:1831-1836

53. Piaggesi A, Schipani E, Campi F et al (1998) Conservative surgical approach versus non-surgical management for diabetic neuropathic foot ulcers: a randomized trial. Diabet Med 15:412417

54. Coffey JT, Brandle M, Zhou H et al (2002) Valuing health-related quality of life in diabetes. Diabetes Care 25:2238-2243

55. Dhawan V, Spratt KF, Pinzur MS, Baumhauer J, Rudicel S, Saltzman CL (2005) Reliability of AOFAS diabetic foot questionnaire in Charcot arthropathy: stability, internal consistency, and measurable difference. Foot Ankle Int 26:717-731

56. Evans AR, Pinzur MS (2005) Health-related quality of life of patients with diabetes and foot ulcers. Foot Ankle Int 26:32-37

57. Willrich A, Pinzur M, McNeil M, Juknelis D, Lavery L (2005) Health related quality of life, cognitive function, and depression in diabetic patients with foot ulcer or amputation. A preliminary study. Foot Ankle Int 26:128-134

58. Goodridge D, Trepman E, Sloan J et al (2006) Quality of life of adults with unhealed and healed diabetic foot ulcers. Foot Ankle Int 27:274-280

59. Tarride JE, Gordon A, Vera-Llonch M, Dukes E, Rousseau C (2006) Cost-effectiveness of pregabalin for the management of neuropathic pain associated with diabetic peripheral neuropathy and postherpetic neuralgia: a Canadian perspective. Clin Ther 28:1922-1934

60. Tolle T, Xu X, Sadosky AB (2006) Painful diabetic neuropathy: a cross-sectional survey of health state impairment and treatment patterns. J Diabetes Complications 20:26-33

61. Casellini CM, Barlow PM, Rice AL et al (2007) A 6-month, randomized, double-masked, placebo-controlled study evaluating the effects of the protein kinase $\mathrm{C}-\beta$ inhibitor ruboxistaurin on skin microvascular blood flow and other measures of diabetic peripheral neuropathy. Diabetes Care 30:896-902

62. Lewko J, Politynska B, Kochanowicz J et al (2007) Quality of life and its relationship to the degree of illness acceptance in patients with diabetes and peripheral diabetic neuropathy. Adv Med Sci 52 (Suppl 1):144-146

63. Nelson SC, Little ER Jr (2007) The 36-item Short-Form Health Survey outcome evaluation for multiple lower-extremity nerve decompressions in diabetic peripheral neuropathy: a pilot study. J Am Podiatr Med Assoc 97:121-125

64. Happich M, John J, Stamenitis S, Clouth J, Polnau D (2008) The quality of life and economic burden of neuropathy in diabetic patients in Germany in 2002-results from the Diabetic Microvascular Complications (DIMICO) study. Diabetes Res Clin Pract 81:223-230

65. Lavery LA, Murdoch DP, Williams J, Lavery DC (2008) Does anodyne light therapy improve peripheral neuropathy in diabetes? A double-blind, sham-controlled, randomized trial to evaluate monochromatic infrared photoenergy. Diabetes Care $31: 316-321$

66. Lincoln NB, Radford KA, Game FL, Jeffcoate WJ (2008) Education for secondary prevention of foot ulcers in people with diabetes: a randomised controlled trial. Diabetologia 51:1954-1961

67. Mittlmeier T, Klaue K, Haar P, Beck M (2010) Should one consider primary surgical reconstruction in charcot arthropathy of the feet? Clin Orthop Relat Res 468:1002-1011

68. Spiegelhalter DJ, Gore SM, Fitzpatrick R, Fletcher AE, Jones DR, Cox DR (1992) Quality of life measures in health care. III: Resource allocation. BMJ 305:1205-1209

69. Bann CM, Fehnel SE, Gagnon DD (2003) Development and validation of the Diabetic Foot Ulcer Scale-short form (DFS-SF). PharmacoEconomics 21:1277-1290 